\title{
COMPETENCY BUILDING FOR HEALTH PROMOTION AND CHANGE IN THE CARE MODEL
}

\author{
Luciana Nettoํ, Kênia Lara Silva², Marília dos Santos Rua ${ }^{3}$
}

\begin{abstract}
${ }^{1}$ Ph.D. student, Programa de Pós-Graduação em Enfermagem, Universidade Federal de Minas Gerais (UFMG). Professor, Universidade Federal de São João del-Rei. Divinópolis, Minas Gerias, Brazil. E-mail: luciananetto@ufsj.edu.br

2 Ph.D. in Nursing. Professor, Escola de Enfermagem, UFMG. Belo Horizonte, Minas Gerais, Brazil. E-mail: kenialara17@gmail.com

${ }^{3}$ Ph.D. in Nursing. Professor, Escola Superior de Saúde, Universidade de Aveiro. Aveiro, Portugal. E-mail: mrua@ua.pt
\end{abstract}

\begin{abstract}
Case study based on the theoretical and methodological framework of dialectics, aimed at analyzing competency building for health promotion, from the perspective of graduates from a nursing course and its relation to change in the care model. Interviews focused on competencies were held with ten graduates. Data were analyzed using critical discourse perspective. The results show that the competencies for health promotion, defined by two internacional consensus, were discussed in the course of the nursing education process. The discourses demonstrate that competency building for health promotion in nursing education can foster change in the care model, despite the challenges in this process. Curricular strategies like contact with reality through the immersion of students in the practical scenario since the beginning of the course and community service and research activities can contribute to competency building for health promotion in nursing education and foster the change in the care model.
\end{abstract}

DESCRIPTORS: Health promotion. Competency-based education. Nursing

\section{DESENVOLVIMENTO DE COMPETÊNCIAS PARA PROMOÇÃO DA SAÚDE E MUDANÇA NO MODELO ASSISTENCIAL}

RESUMO: Estudo de caso ancorado no referencial teórico-metodológico da dialética, com o objetivo de analisar o desenvolvimento de competências para promoção da saúde, na perspectiva dos egressos de um curso de enfermagem, e sua relação com a mudança do modelo de atenção. Foram realizadas entrevistas com foco em competências com dez egressos. Os dados foram analisados pela perspectiva crítica do discurso. Os resultados demonstram que as competências para promoção da saúde, definidas em dois consensos internacionais, foram trabalhadas ao longo do processo de formação. Os discursos produzidos demonstram que o desenvolvimento de competências para promoção da saúde pode favorecer a mudança do modelo assistencial, apesar dos desafios neste processo. As estratégias curriculares de contato com a realidade, por meio da imersão do estudante no cenário de prática, desde o início do curso, e ações de extensão e pesquisa podem contribuir para o desenvolvimento de competências para a promoção da saúde e favorecer a mudança do modelo assistencial. DESCRITORES: Promoção da saúde. Educação baseada em competências. Enfermagem.

\section{DESARROLLO DE COMPETENCIAS PARA LA PROMOCIÓN DE LA SALUD Y CAMBIO DE MODELO DE ATENCIÓN}

\begin{abstract}
RESUMEN: Estudio de caso anclado en la dialéctica, con el fin de analizar el desarrollo de competencias para la promoción de la salud, desde la perspectiva de egresos de un programa de enfermería y su relación con el cambio del modelo de atención. Las entrevistas con enfoque en competencias con diez graduados de una licenciatura en enfermería. Los datos fueron analizados por análisis crítico del discurso. Los resultados muestran que competencias para promoción de la salud, definidas en dos consensos internacionales, se trabajaron durante todo el proceso de formación. Los discursos producidos muestran que este desarrollo de competencias puede fomentar el cambio del modelo de atención, a pesar de los desafíos en este proceso. Se necesita mayor cambio de paradigma, ya que el suelo parece fecundo para este proceso. Las estrategias curriculares de contacto con la realidad, a través de la inmersión del estudiante en el escenario de práctica desde el inicio del curso, y las actividades de extensión e investigación pueden contribuir al desarrollo de competencias para la promoción de la salud en la formación de enfermería y fomentar el cambio del modelo de atención.
\end{abstract}

DESCRIPTORES: Promoción de la salud. Educación basada en competencias. Enfermería. 


\section{INTRODUCTION}

The proposal to replace the hegemonic health care system by models that value integrality, humanized care and health promotion has not been conquered and to a large extent, it depends on the education profile and practice of the health professionals. ${ }^{1}$

Health promotion is a current field and can be understood as a training process of individuals who intend to improve, control and manage their health process and quality of life. ${ }^{2-4}$ Its formulation as a dimension of a health policy has been part of ideological discourses since the 1970's, gaining form and expression in 1986 at the I International Conference of Health Promotion in Canada. ${ }^{4}$

The health promotion movement is intended to overcome the voids in the biomedical model, articulating the entire society to improve the quality of life of individuals and the group. Nevertheless, overcoming the traditional and hegemonic model represents a challenge in the construction of another health paradigm that takes into account the individuals and groups' daily events in the ways of life and in the determination of the health-disease process. ${ }^{5}$

For the health professionals to effectively act in the contemporary context, it is fundamental to define the necessary competencies, considering the complexity of the health policy and its implementation. Among these competencies, the specific competencies to work in health promotion are highlighted, which refer to a combination of knowledge, skills and essential values needed for the effective practice of individual or collective health promotion actions. ${ }^{6}$

The Declaration deriving from the Galway Consensus and the European Project CompHP (Developing Competencies and Professional Standards for Health Promotion Capacity Building in Europe) outlines fundamental values and principles and provide a common definition and core competency domains for the people who engage in health promotion practices, that is: production of changes, health advocacy, partnerships, communication, leadership, diagnosis, planning, implementation and assessment. ${ }^{7-9}$ These domains should be sustained and should function in combination with the ethical values and knowledge in health promotion actions. ${ }^{6-7}$

The education process should be capable of preparing the health professionals, independently of their category, to work in health promotion, allowing them develop the capacity to mobilize the core competencies in this field..$^{7-8}$ The remain- ing competencies, knowledge, values and skills to change the practices and policies in force will come from the continuing education process.

Discussions on nursing education to work in health promotion can be identified in the international literature, ${ }^{6,10-11}$ but gaps remain concerning the competencies developed in this process and the teaching strategies that result in professional standards appropriate to the transformation of health practices.

In that sense, the question is raised how competencies are built for health promotion in nursing education and what pedagogical strategies function as devices for this education?

Against this background, the objective in this study is to analyze competency building for health promotion from the perspective of graduates from a nursing course and its relation with change in the healthcare model.

\section{METHOD}

A qualitative case study was undertaken, based on the theoretical-methodological framework of Marxist dialectics. ${ }^{12-15}$

Interviews were held with a focus on competencies involving ten graduates, out of 57 nurses graduated from the first two classes of a public higher education institution in the Minas Gerais State.

The graduates were contacted through a presentation and invitation by e-mail to participate in the research. The e-mail addresses registered at the student administration of the place of study were used. Ten graduates accepted the invitation. Despite the interest manifested in the research, the remainder declined the invitation because they were working or taking a master's/doctoral program in other cities or states distant from the place of study. The interviews were held between July and November 2014.

To collect the data, interviews were held with a competency or behavioral focus, an organizational psychology tool that has been used in human resource recruiting and selection processes. Through this technique, the interviewer intended to collect examples of situations the interviewee had experienced, trying to discover what he did, felt and thought and what the results of the action were in a certain situation.

The interview was guided by the following questions: tell me about a health promotion practice you developed as a student or professional; report 
on a moment during your undergraduate course that allowed you to develop health promotion in your work environment; or describe a health promotion practice for which you took the responsibility and how your undergraduate course in nursing prepared you.

All interviews were audio-recorded with the participants' permission, who signed the informed consent form after clarifications on the purpose of the study. To avoid identification, each graduate received a code, consisting of the letter $\mathrm{G}$ (graduate) followed by a sequential number.

To score the health promotion competencies, facilitate the consolidation of the large volume of empirical material and manage all data for analysis, the software webQDA*, version 2013 was used to support the qualitative data analysis in a collaborative environment. ${ }^{16}$

The researcher transcribed the interviewees' spoken and recorded discourse, maintaining oral registration elements like intonation, emphasis, pause, changes in the voice pitch and rhythm. Therefore, transcription conventions and models were considered, ${ }^{17-19}$ concerning the guidelines for discourse analysis resources. Some signs, such as $/,[\ldots]$ and words in uppercase, between inverted commas, brackets, squared brackets and underlined words in the study participants' discourse refer to items in the transcription convention and models. These items correspond to interruptions in the discourse flow, pauses, silence, comments, literal citations and emphasis in the voice, which are relevant in the discourse analysis.

To assess the quality of the data, after the interview, the transcriptions were carefully read to verify whether the data in the material were sufficient for the analysis. The fieldwork was closed off when the empirical research context had been designed.

The analysis of the material from the interview was guided by the critical perspective, in view of the theoretical approach and the method to study the discourse. In that approach, articulating linguistics and critical social science, the discursive events were analyzed in view of three dimensions (text, discursive practice and social practice) in the sociohistorical context and the social transformations. ${ }^{18-19}$

First, through a horizontal analysis of the narratives in the transcription of the individual in- terviews, the regularities and singular experiences were identified through the meanings underlying the ideas described in the discourse. Next, through a vertical analysis of the material obtained, the common themes were identified in the collected material which, by establishing mutual relationships, permitted the establishment of the empirical categories. Finally, in an interpretive synthesis, through a crossed analysis, the participants' viewpoints and singular expressions were discussed, confronting them, in a dialectic movement, with the authors' critical interpretation of the analytic categories. ${ }^{18,20}$

The research project underlying this study received approval from the Research Ethics Committee - COEP/UFMG (Opinion No. 694.248 - CAAE 08863612.0.0000.5149), on 06/24/2014 and all phases of this project comply with Resolution 466/2012/ MS on research involving human beings.

The communication of the research results followed the guidelines for qualitative research project results using interviews and focus groups, available in Consolidated criteria for reporting qualitative research (COREQ). ${ }^{21}$

\section{RESULTS}

Among the ten graduates who were interviewed, eight were working in one or more sectors, including primary care $(n=4)$, hospitals $(n=4)$, emergency services $(n=2)$ and teaching and research projects $(n=1)$, totaling an average seven months of work. Eight graduates also take part in graduate programs, in residency and Master's programs.

The results were organized to demonstrate the findings in the dimensions: Competencies for health promotion and Change in the care model. In the first dimension, the participants revealed their understanding about the core attributes of health promotion competencies. In the second dimension, the practical aspects of these competencies were revealed, as well as the relation with the changes in the care model.

The understanding about the competencies was demonstrated through the knowledge, skills and attitudes that constitute health promotion practices. In that sense, the participants associate the knowledge and skills to be acquired over time. The textual element of temporality, manifested through expressions like "we develop that over time", "are

\footnotetext{
WebQDA is software developed by the Centro de Investigação Didática e Tecnologia na Formação de Formadores (CIDTFF) of the Departamento de Educação, Universidade de Aveiro, Portugal, as a tool in the organisation and analysis of qualitative data.
} 
constructed along the way", "since the first period", indicates that competency building is something continuous, whose experience during the undergraduate program, including the early inclusion in professional practice, is but one of the moments.

[...] [takes a deep breath] Well, one positive point I see in my undergraduate course is that, since the first term, we were taking part in practicums, that's/ training, / so we gained a view of the context, of the reality of health, [...] And the skills I think we develop that over time (G 01).

The discourse indicates that, in competency building for health promotion, a dominant logic prevails in which knowledge is rated higher than skills and attitudes in the discourse.

What are the competencies? [...] know/ he needs knowledge, [...] about what he wants to promote [...] (G 10).

We need the knowledge to be able to pass, so we always need to study, gain updated knowledge ABOUT the theme we are aiming for; secondly we need an attitude, a desire to put that in practice, [...] (G 01).

The practitioners of health promotion should also take into account the determinants of health and the reality of the context the people are inserted in. According to the participants, they gained this view for the first time during the undergraduate course. The graduates also mentioned health as an unalienable right of human beings, referring to the duties of the governments in this process.

Eh [...] it's/ it was reality really./ The reality of the service. That was very important./ It's because [...] in my life I never used to attend the health service, we've always had a health insurance at my home and we never used to go to the emergency service, to the hospital. We never did. So I got to know that reality here [...], mainly in the poorest regions. Then I realized the population's difficulty, the importance of access for this population, of promoting activities, [...] Because it's really promoting, so as not to be a curative model. So, it's perceiving these people's difficulties [...] what is missing in their lives, the lack of information, the lack of education that also makes things difficult, which we notice in low-income people. That's very important (G 09).

The government's need to promote a health insurance compatible with each region, each culture and population, and to keep in min that health is a right of all and a duty of the State to provide it, that's why we need to claim high-quality health for all (G 02).

The findings lead to the analysis of the challenges to develop health promotion actions as a social practice, acting on the lacks and threats to change the hegemonic health model. That responsibility is attributed to the State, as the actor responsible for conducting and guaranteeing the right to health in the country.

The graduates appoint the legal support and the defense of health as strategies that permit health promotion actions. The legislation is learned in the course of the education process and stimulates the participation in actions of civil activism.

It's, we / in the $6^{\text {th }}$ and $7^{\text {th }}$ term we have / we get knowledge of the laws / of health, [...] and that knowledge makes [(00:06:12)], it shows you the importance of /protesting on behalf of/, of that development of health. Then, you can protest and develop criticism towards what needs to improve. [...] (G 04).

In the same dimension, the ethical values were addressed, referring to the belief in equity and social justice, respecting autonomy and individual and group choice in a participatory and collaborative form of work. In that sense, the textual element of the metaphor was used to discuss how the relationships with people, families and the community should be: the interviewees mentioned that the professionals need skills to adapt their practices to the contexts, taking into account the characteristics of people, families and communities, avoiding generalizations, bundling.

[...] treat the patient as a whole, respecting is / the patient's decisions too, not wanting, it's / bundling the patient in a single place, in a package. Think that everyone's equal. He needs to respect the differences of each I to try and promote health, because that individual, he too,/ [pause to elaborate the response] he/ because he too is capable of receiving that moment (G 10).

The graduates mentioned that the health promotion actions in partnership with other social sectors positively influence people's lives and the health services. In that sense, the development of partnerships was mentioned as a strategy for competency building with a view to health promotion.

Hum, let me see [...] Hum, hum/ no, yes we did / there was a group we worked with from the training program, [...] because we did / a / we collected funding to organize the actions on the square, we had the breastfeeding walk. So there was the partnership among the University, the health department, the municipal government / [(00:07:15)] (G 06).

So, at the service mainly, I've got several ideas [...] starting to develop a group of pregnant women too, to prevent a risky pregnancy, [...]. We are constituting a group to work with the adolescents in the schools too, lectures, activities in school / this partnership is being 
developed. So I think that everything you can do to reduce the service's demand, for the person to find out why he's got a disease, that's a health promotion activity (G 05).

The planning of health promotion actions was mentioned as a competency domain for health promotion developed during the undergraduate course. The graduates refer to the organization of the activities they accomplished throughout the course and in professional practice, such as actions on the squares, markets, encounters, in hospitals or primary health care services.

But, and/UNDERGRADUATE EDUCATION, why was it important? She has shown that since the first term. So, like, we / knew about the difficulties, [...] we knew that it is difficult, you need to plan, you need to ask the agent / for the agent to go there, call, recall, send the invitation [...] and / I remember that / in the first term we arrive totally immature, [...] You don't have much of that notion that you need to study in advance,/ but something always happened each term to contribute to the promotion of (health)/ for the proposed activity to be better than it was before/. That is beyond doubt (G 08).

In the social mobilization, the graduates discuss how they have stimulated the population to take part in the activities proposed, intended to improve the quality of life, such as walks and gymnastics. The mobilization is considered important to grant visibility to the social demands.

It was there at/in the rural practicum, in (name of a village near the city where the course is located)./ I used to stay at the health service and / when I got there we had to do something, some movement for promotion. And/I had the idea of mobilizing the population to have gym class in the morning / (G 10).

\section{DISCUSSION}

The findings remit to a construction process of the new care model, which is intended to replace the biological, medical-centered model, focused on disease and individual care, which is still in force nowadays. ${ }^{22-23}$ There is evidence that signals this movement of rupture, represented by the awareness that the current practices have failed, which ignore the context and the subjects. ${ }^{8}$

The implementation of the new care model requires actions that are centered on the relation of trust among the professionals and between them and the people, the family and the community, promoting self-care, respecting people's dignity, sympathizing and supporting the citizens in conscious decision making, in the attempt to guarantee to right to individual responsibility over one's life and health. ${ }^{22}$ The valuation of the people, evidenced in the participants' discourse, is important for the new health care model. ${ }^{24}$

As evidenced, the new care model under construction tends to approach the recommendations of the World Health Organization and the Unified Health System (SUS), whose focused is centered on the health promotion of individuals, families and communities. This new model seeks to raise the citizens' awareness, trying to stimulate them to practice behaviors, to promote healthy lifestyles and to enable them for shared decision making in the complex situations of daily life, towards the exercise of citizenship and the strengthening of the community. ${ }^{4,25}$

These aspects, defined since the Ottawa Charter $^{4,26}$ and strengthened in the National Policy for Health Promotion, ${ }^{25}$ demand professionals with other competencies than those traditionally used to work in the medical-hegemonic model.

It is important to highlight that health advocacy, social mobilization, leadership and partnerships are competencies present in the discourse and indicate new modes of doing health. The participants acknowledge that the health promotion actions performed in partnership with other health professionals and other social sectors stimulate the leadership of community members, permit greater dissemination of the proposal and positively influence people's lives and the health services.

These competencies are mainly mobilized in health education and in social movements in defense of health. Other authors appoint this need to mobilize these competencies as a fundamental factor for the efficacy of health promotion actions..$^{7-8}$

On the other hand, it is acknowledged that the change movement is dialectical and faces challenges in view of the old that insists in staying in place. In that sense, the marks of knowledge and information transmission, which go against the perspective of active subjects, and the actions on the social determinants are also mentioned in the discourse, especially concerning the communication domain and the execution of competencies for health promotion.

Hence, to advance in the construction process of the new care model, the discourse demonstrated that the nurses have mobilized health promotion competencies developed in their education process, in the academy as well as in life. ${ }^{27}$ From a temporal perspective, this competency building is ongoing and not limited to the undergraduate course. 
In academic life, however, as a privileged space for education, the induction of the paradigmatic change in the care model is built on the approach, as early as possible, with the contexts of the health services' professional practices. ${ }^{28}$

To revert the biomedical rationality that rules in schools, some curricular strategies, such as student immersion in practicums with active learning since the start of the course, contribute to the contact with the reality of the population's life and health and its determinants. ${ }^{28}$ Living and living together in the service context, gaining know-how in practice favors reflection and competent action in the search for solutions for professional practice. Competency building is facilitated in this inclusion, as it permits the elaboration of intervention proposals and the development of effective and sustainable actions to promote health and reduce inequities, based on respect for human beings and their diversity. ${ }^{22,29}$

Hence, at times of structural change in the health care models, the educative process is considered particularly important for core competency building for the new social practices, driven by other ideologies. In that sense, this study underlines the following thought, ${ }^{30}$ that to fight dominant policies, one should encourage the dialogic democracy to guarantee the freedom of expression and recovery the true sense of being citizens. Thus, one can "analyze based on information and critical sense what is happening in society and create willingness and positive attitudes of cooperation and participation in the solution of collective problems". ${ }^{30: 50}$

\section{FINAL CONSIDERATIONS}

In this study, the social practice expresses ideas that remit to the overcoming of the hegemonic care model. Nevertheless, the reproductive nature of the practices is also maintained, including the transmission of knowledge and information presented as challenges for social transformation.

As characteristics of the new model, health promotion is presented as an important practice, learned in an integrated manner in the course of the education process.

Competency building for health promotion is learned in practice, continuously and daily, based on the students' inclusion in the health services, which favors their learning through contact with the population and the development of autonomy and critical sense.

The findings indicate that the curricula's innovative strategies can break with the social matrix of the reproductive, regulatory and conventional discourse and encourage creativity and inventions in nursing education, furthering the competencies of social mobilization, health advocacy and partnerships. These are changes that sustain the rupture and movement of transformation in the health care model.

Nurses with core competencies in health promotion play an important role to guarantee the integrated perspective and effectiveness of the actions in the new model, permitting reflections on the practices and contributing to the ongoing change process.

As study limitations, it can be mentioned that the results described are restricted to the context the study was developed in and the time period considered. The researchers attempted to guarantee the strict execution of the methodological process to minimize the expression of subjectivity implicit in qualitative research. These study results suggest further research in different contexts for the sake of comparisons with other national and international contexts.

\section{REFERENCES}

1. González AD, Almeida MJ. Integralidade da saúde: norteando mudanças na graduação dos novos profissionais. Cien Saude Colet. 2010;15(3):757-62.

2. Glanz K, Rimer BK,Viswanath K, organizadores. Health behavior and health education: theory, research, and practice. $4^{\text {th }}$ ed. San Francisco (US): Jossey-Bass; 2008.

3. Greiner PA, Edelman CL. Health defined: objectives for promotion and prevention. In: Edelman CL, Mandle CL, organizadores. Health promotion: througthout the life span. $7^{\text {th }}$ ed. St. Louis (US): Mosby Elsevier; 2010. p.3-25.

4. World Health Organization. The Ottawa Charter for Health Promotion. First International Conference on Health Promotion; Ottawa, Canada. Geneve $(\mathrm{CH})$ : World Health Organization; 1986.

5. Silva KL, Sena RR, Belga SMMF, Silva PM, Rodrigues AT. Health promotion: challenges revealed in successful practices. Rev Saúde Pública. 2014; 48(1):76-85.

6. Dempsey C, Barry MM, Battel-Kirk B. TheCompHP Core Competencies Framework for Health Promotion Handbook. Paris (FR): IUPES; 2011.

7. Barry MM, Battel-Kirk B, Davison H, Dempsey C, Parish R, Schipperen M, et al. The CompHP Project Handbooks. Paris (FR): International Union for Health Promotion and Education (IUHPE); 2012.

8. Fragelli TBO, Shimizu HE. Competências profissionais em Saúde Pública : conceitos, origens, abordagens e aplicações. Rev Bras Enferm. 2012; 65(4):667-74. 
9. Allegrante JP, Barry MM, Auld ME, Lamarre M-C, Taub A. Toward international collaboration on credentialing in health promotion and health education: The Galway Consensus Conference. Heal Educ Behav. 2009 June; 36:427-38.

10. Arroyo HV. Professional training and competency development for health promotion capacity building in Latin America. Glob Health Promot. 2009; 16(2):6672.

11. Battel-Kirk B, Barry MM, Taub A, Lysoby L. A review of the international literature on health promotion competencies: identifying frameworks and core competencies. Glob Health Promot. 2009; 16(2):12-20.

12. Konder L. O que é dialética. $28^{a}$ ed. São Paulo (SP): Brasiliense; 2004.

13. Marx K. O capital. 2a ed. São Paulo (SP): Abril Cultural; 1983.

14. Minayo MCS. O desafio do conhecimento: pesquisa qualitativa em saúde. 13 ${ }^{a}$ ed. São Paulo (SP): Hucitec; 2013.

15. Minayo MC de S. Pesquisa Social: teoria, método e criatividade. 34 ed. Petrópolis (RJ): Vozes; 2015.

16. Souza FN, Costa AP, Moreira A. WebQDA: Software de apoio à análise qualitativa. Atas da $5^{\mathrm{a}}$ Conferência Ibérica de Sistemas e Tecnologias de Informação (CISTI2010). Santiago de Compostela, Espanha: Associação Ibérica de Sistemas e Tecnologias de Informação; 2010. p. 293-8.

17. Kock IV. A inter-ação pela linguagem. São Paulo (SP): Contexto; 2010.

18. Fairclough N. Discurso e mudança social. Brasília (DF): Editora Universidade de Brasília; 2008.

19. Magalhães I. Teoria crítica do discurso e texto. Ling em (Dis)curso. 2006; 4(Esp):113-31.

20. Gomes R, Souza ER, Minayo MC de S, Malaquias JV, Silva CFR. Organização, processamento, análise e interpretação de dados: o desafio da triangulação. In: Minayo MCS, Assis SG, Souza ER. Avaliação por triangulação de métodos: abordagem de programas sociais. Rio de Janeiro (RJ): Fiocruz; 2005. p. 185-221.

21. Tong A, Sainsbury P, Craig J. Consolidated criteria for reporting qualitative research (COREQ): a 32-item checklist for interviews and focus groups. Int J Qual Health Care; 2007; 19(6):349-57.

22. Alves E, Oliveira MAC. O desenvolvimento da competência crítica e reflexiva no contexto de um currículo integrado. Londrina (PR): iNESCO; 2014.

23. Keller-Franco E, Kuntze TD, Costa LS. Inovação curricular na formação dos profissionais da saúde. Rev e-curriculum. 2012; 8(2). p.1-14.

24. Fertonani HP, Pires, DEP, Biff D, Scherer MDA. The health care model: concepts and challenges for primary health care in Brazil. Ciênc Saúde Coletiva. 2015 Jun; 20(6):1869-78.

25. Ministério da Saúde (BR). Política Nacional de Promoção da Saúde: PNPS: revisão da Portaria MS/ GM no 687 de 30 de março de 2006. Brasília (DF): MS; 2015.

26. Heidmann ITSB, Almeida MCP, Boehs AE, Wosny, $\mathrm{AM}$, Monticelli, M. Promoção à saúde: trajetória histórica de suas concepções. Texto Contexto Enferm. 2006; 15(2):352-8.

27. Santos SSC, Hammerschmidt K. Complexity and the reconnection of interdisciplinary knowledge: contribution of Edgar Morin's thoughts. Rev Bras Enferm. 2012; 65(4):561-5.

28. Garcia MAA, Kather B. Construindo vínculos, aprendendo saúde: estudo de revisão. Rev APS. 2012 Out-Dez; 15(4):496-507.

29. Souza PA, Zeferino AMB, Da Ros MA. Currículo integrado: entre o discurso e a prática. Rev Bras Educ Med. 2011; 35(1):20-5.

30. Santomé JT. A construção da escola pública como instituição democrática: poder e participação da comunidade. Currículo sem Front. 2001 Jan-Jun; $1(1): 51-80$.
Correspondence: Luciana Netto

Rua Sebastião Gonçalves Coelho, 400. Sala 301.4 Bloco D

35501-296 - Chanadour, Divinópolis, MG, Brasil.

E-mail: luciananetto@ufsj.edu.br
Received: June 30, 2015

Approved: November 03, 2015 